INFO- 139

Primljeno/Received:2019-02-13

10.32914/mcpr.10.1.4
UDK: 342.721:316:1

Preliminary Communication/Prethodno priopćenje

\title{
POIMANJE SLOBODE KAO PRIRODNOG PRAVA
}

\author{
Zdravko Šorđan \\ Teološki institut, Beograd, Srbija
}

\begin{abstract}
Sažetak
Pojava pokreta je obično reakcija na postojeće stanje i javljaju se kao duhovno nezadovoljstvo i negodovanje na devijantne pojave, želja za formiranjem novog identiteta, unutarnji nemir, duhovno gibanje; pokušaj da se dosegnu viši ciljevi; napor da se teorija prevede u praksu. Ako su ispravno motivirani javljaju se kao sveti zanos, a bez tog zanosa nema i ne može biti duhovne obnove. "Svatko tko odbacuje utopiju ostavlja čovječanstvo na milost i nemilost istrumentalnoj racionalnosti", prepušta ga "želji za moć" manipuliranju i diktaturi". (A.Heller) Oni se, dakle, javljaju kao posljedica nezadovoljenih potreba, kao reakcija na duhovnu anemičnost i inertnost, pa stoga streme ka većim duhovnim promjenama. Svaki novostvoreni život ima svoj ritam koji ne priznaje okoštale forme, i stremi harmoničnom zajedništvu.
\end{abstract}

Ključne riječi

sloboda, reformacija, pokret, društvo, crkva, savjest

U prvim stoljećima kršćanstva religija se obično prenosila klasičnom metodom putem usmjene propovijedi. Tako je Crkva postupno stekla moć nad informacijskim sustavom toga vremena. Napose, od IV stoljeća, kada je Milanskim ediktom 313. godine car Konstantin priznao i državnu religiju proglasio službenom, Crkva pokazuje neskrivenu tendenciju da vlada, ne samo "carstvom duha, nego i carstvom ćesara" /1/. Njoj pripada moć nad narodima i zemljama, moć da postavlja i smjenjuje careve i vladare. Pošto je stekla gotovo neograničenu moć, Crkva uvodi Inkviziciju kao instituciju koja treba da zaštiti njezine interese, tj. interese crkvenog vladara putem stroge kontrole - cenzure kao čuvara kršćanskog učenja. Zadaća ove institucije bila je da spriječava cirkulaciju izvornih i slobodoumnih kršćanskih ideja putem jakog monopola nad informacijama.

To je ujedno i bio monopol nad ljudskom slobodom, slobodom ličnosti, a ličnost nije samo biološka kategorija, ona je prije svega etična i duhovna kategorija, tako, sloboda je uvjet bez kojega ne može biti duhovne obnove, jer tamo gdje nema slobode nema ni istine. Istina traži slobodu za onoga tko je otkriva i slobodu za one koji je prihvaćaju. Okoštavanje vjere znači prekid kretanja i duhovnog uspona a gdje nema kretanja nema ni života, jer život nije statičan on je dinamičan. Ako nema trpeljivosti znači nema ni rasprave ako nema rasprave nema ni upitnosti, a bez upitnosti nema istine - što više duha više slobode manje duha više materije. Pravo na slobodu je kao božanska datost, osnovno prirodno pravo čovjeka, a prirodno pravo je jače i mjerodavnije od svakog pisanog zakona. Slobodu ne daje ni država, ni društvo, ni crkva, ni pojedinac, ona je jednostavno božanska datost.

Čovjek je stvoren i pozvan da bude slobodno biće, odgovoran Bogu i svojoj savjesti. Sve težnje koje se pojave u državi i društvu i koje imaju za cilj da se čovjek liši mogućnosti da odgovorno djeluje znače poricanje božanskih namjera u odnosu na čovjeka. U konačnoj analizi, osnov svih prirodnih ljudskih prava je dostojanstvo i nepovredivost ljudske slobode i savjesti. Dakle, ispoljavanje čovjekove savjesti mora se promatrati u okviru prava drugih 
ljudi i pravednih, nepristrasnih društvenih odnosa.

Sloboda misli i reči nužna je kao uvjet za razvoj znanosti i umjetnosti, isto tako i za opći intelektualni, kulturni i duhovni napredak.

Crkva se uvjek nalazi u opasnosti da postane služavka grupe ljudi koji su na vlasti ili snažnih udruga, pa da time izgubi mogućnost da prema njihovim kulturnim i društvenim pretpostavkama održava kritički razmak. Crkva može vršiti svoju misiju i kritičku ulogu samo onda ako može izbeći da se čvrsto povezuje sa kulturnim i ideološkim modelom koji su na vlasti. Humbolt ističe da je "svrha države postignuta kad se njeni zakoni poštuju; zakonodavac je izvršio svoju dužnost ako donosi mudre zakone i umije da kod svojih građana obezbijedi njihovo poštovanje" /2/.

Osnovna ljudska prava na koja Luter poziva civilne vlasti sastoje se u zaštiti svakog čovjeka koji se brine za svog bližnjeg. U svom "Komentaru o Veličanstvu" iz 1521. godine Luter razlikuje dva plana ljudskog života. U apsolutni plan spada vjera ili Evanđelje koje predstavlja najveće dobro i nitko ga ne bi trebalo zanemariti. /3/ U svakom slučaju, naglašava Luter, "nitko jednom čovjeku ne može oduzeti vjeru i istinu, čak i ako mu oduzme život".

$\mathrm{U}$ drugom djelu svoje rasprave "O privremenom autoritetu" iz 1523. godine on oštro ističe granicu privremjene sile pa kaže: "Duša izmiče svakoj ljudskoj zamci i priznaje samo Božju silu' $/ 4$ /

Dakle, ispoljavanje čovjekove savjesti mora se posmatrati u okviru prava drugih ljudi i pravednih, nepristrasnih društvenih odnosa.

Sloboda misli i riječi nužna je kao uvjet za razvoj znanosti i umjetnosti, isto tako i za opći intelektualni, kulturni i duhovni napredak. Bog izravno daje svoja dobra čovjeku, kome je neposrijedno pristupačna vjera i Biblija. Iz te temeljne činjenice, ispisane na samom Božjem djelu, proističe ono što možemo nazvati slobodom ljudske savjesti. Duša izmiče svakoj ljudskoj zamci i priznaje samo Božju silu. Vjera je božansko djelo koje proističe iz Duha i prema tome nijedna vanjska sila ne može se nametnuti, niti je osporavati.

Budući da sam Bog daje vjeru i ne dopušta čovjeku da svoje povjerenje podredi zemaljskom autoritetu, čovjek u osnovi ima pravo da se odupre svakoj sili ili autoritetu koji pokazu- je namjeru da ovlada slobodom ili njegovom ličnošću, a čovjek je ličnost ne samo po prirodi nego i po duhu. "Svako potčinjavanje ličnosti pojedincu ili društvi produžetak je prinašanja ljudskih žrtava"'.

Inkvizicija je proglasila za herezu sve što je bilo napredno, svaki zračak svjetlonosne istine koji je pokušavao obasjati područje čovjekovog života i njegove djelatnosti. Surovo je sprovodila cenzuru, ne samo nad pisanom riječju nego i nad slobodom savjesti. Sloboda koja ne poznaje sažaljenje je demonska.

U svakom slučaju, sasvim je sigurno da su se inkvizicijske zabrane odnosile i na Bibliju $u$ tumačenjima luteranskih i kalvinističkih autora. Testas je o tomu pisao:

"Historijska znanost razlikuje tzv. rimsku inkviziciju, tj. crkveni sud ustanovljen u XIII stoljeću s ciljem da na području Zapadne crkve iskorijeni vjerovanja i obrede koji nisu u skladu s kršćanskom vjerom i religioznom praksom Crkve, od tzv. španjolske inkvizicije, utemeljene 1. studenog 1478. godine u obranu društvenih, kulturnih i religioznih vrednota španjolskog katolicizma, a koja će vremenom prerasti u oružje državnih vlasti i dobro uhodani sustav društvene kontrole.

Inkvizicija je progonila i kažnjavala svako ponašanje koje je, izravno ili neizravno, dovodilo u pitanje disciplinu Rimske crkve ili neku od njezinih vjerskih učenja, bez obzira

na to radi li se o riječima, znakovima ili vladanju protivnom rimskom uzoru" /5/.

To se razdoblje s pravom može nazvati paralizom misli. Knjige koje su bile pripravljene za tisak podvrgnute su dvostrukoj cenzuri, jednom prije davanja u tisak i drugom kontrolom poslije izlaska iz tiska. Bez ove dvostruke cenzure svatko je djelo bilo zabranjeno.

Jasno je da je ovaj dogmatski nazor udaljavao od svakog intelektualnog prosuđivanja i da se zbog toga inkvizicija optuživala kao ona koja "ugnjetava misao".

Ovdje moramo istaknuti da $\mathrm{u}$ Index librolum prohi-bitorumu ne nalazimo nijednog filozofa antike, nijednog filozofa srednjeg vijeka, niti kršćanskog, niti arapskog, niti židovskog. Mogli su se čitati talijanski filozofi, bar kada je riječ o Španjolskoj /6/. 
Namjera inkvizicije bila je zaustaviti prodor luteranskog protestantizma. Luteranska propaganda surovo je zaustavljana.

Pojavom reformacije $\mathrm{u}$ XVI stoljeću scena na društvenom, ekonomskom, političkom i vjerskom životu se mijenja. Pojavljuju se novi crkveni dokumenti koji stvaraju uvjete za rađanje nove društvene svijesti. Ona uvjetuje novi komunikativni obrazac koji utječe i na stvaranje novog shvaćanja demokracije. Odlika te nove demokracije ogleda se $\mathrm{u}$ duhovnom stvaralaštvu čovjeka, u osvajanju osobne slobode, u shvaćanju osobnih vrijednota čovjeka, stvorenoga po božanskom obličju. Jer Bog ne inzistira na vlastitom priznanju. On to stavlja čovjekovoj slobodi i njegovu slobodnom odlučivanju. Bog ne rabi silu u stvaranju nekog odnosa s čovjekom, već uspostavlja dvosmjernu komunikaciju, pa čak i prema onima koji drugačije misle. Među slobodnim ljudima sve bolje napreduje i funkcionira, sve se rascvetava i proširuje, sve su porodične veze prisnije, kod slobodnih ljudi dolazi do težnje za nečim višim. Reformacija u XVI stoljeću predstavlja duhovni preobražaj i početak nove epohe $u$ definiranju ličnosti, čovjekovih prava i odgovornosti. Riječ je o prelasku na narodni suverenitet i stvaranju države putem fiktivnih društvenih ugovora ili ustava.

Protestantizam postaje graditelj i promoter moralnosti, duhovnosti, duhovnih vrlina i božanskog jedinstva ljudi. Toliko je važna sloboda duha, koliko je štetno svako ograničavanje te slobode. Oda protestantizmu ima opravdanje i oslonac kroz propovjedi koje pozivaju vjerništvo na reformu i duhovnu obnovu života i prakse.

Postaje korektivna komponenta društva, uspostavlja princip jednakosti i jedinstva pred Bogom, što će prerasti $u$ jednakost ljudi na zemlji. Princip jednakosti predstavlja jednu od komponenti ljudskih prava.

Neosporno je da je protestantizam apsorbovao moralne vrijednote, promovirao se i ugradio $u$ globalne vrijedonosne standarde, odnosno $u$ suvremene međunarodne moralne i pravne norme. Glavni cilj reformacije bila je upravo moralna obnova kršćanstva, a time i društva. Bila je to moralna obnova kršćanstva iz mraka duhovne učmalosti srednjeg vijeka. Od reformacije pa na ovamo širi se i produbljuje humanistička duhovnost i humanistički pogled na svijet. Proces reformacije pokazao je da kršćanstvo nije okoštala i okamenjena religija, nego moralno i životno progresivna, $u$ čijem okrilju je razvijena danas vodeća civilizacija.

Vrijedno je zapaziti da Luter u „Komentaru o Veličanstvu“ pravi bitnu razliku, s jedne strane o općim i osnovnim pravima čitavog društva, t.j. elementarnim dobrima života kao što su: novac, tijelo, čast, žena, djeca, prijatelji i drugo. To su iskazi koji se često pojavljuju kada Luter karakterizira ljudsko postojanje $\mathrm{u}$ njegovom najelementarnijem obliku, to područje reguliraju društveni za-koni. $S$ druge strane, nalaze se „dobra uma i mudrosti“, sposobnost čovjeka da ima svoje mišljenje, da upravlja svojim životom pomoću znanja i mudrosti i svog neprikosnovenog prava na slobodu. Ovim dobrima čovjek suvereno vlada.

Postavlja se pitanje kako pomiriti zakon ljubavi sa intervencijom sile $\mathrm{u}$ očuvanju osnovnih elementarnih sloboda građanskog društva?

Početak 1525. godine je vrijeme kada se osnivaju teritorijalne protestantske crkve, kada se pojavio problem primjenjivanja prava savjesti i verske trpeljivosti u odnosu na jeretike."Vjera je slobodan čin i nitko na to ne može biti prisiljen," bio je Luterov osnovni princip /7/.

Iz toga je on zaključio da ne treba prisiljavati jeretike na bilo što, niti ih ubijati, niti ih fizički siliti da promijene mišljenje. Sukob s anabaptistima i spiritualistima svih vrsta, kao i nemiri izazvani duhovima koji su, pozivajući se na reformu, bili, ipak, daleko od nje, praviće probleme $\mathrm{u}$ krilu teritorijalne protestantske crkve. Luter će biti primoran da precizira da građanske vlasti imaju pravo i dužnost da interveniraju kad jeretici remete javni mir i šire anarhiju. Jasno je, ovdje treba naglasiti, da se intervencija građanskih vlasti ne može odnositi na samu savjest, već samo na njegovu javnu djelatnost. Po Luteru, kršćanin se može sam boriti za svoju pravdu, budući da su njegova oružja nenasilje i riječ. Za vrijeme građanskoga rata Luter će ostati doslijedan samome sebi.

Srednji vijek bio je vrijeme $u$ kojemu se uspostavlja monopol nad sredstvima informiranja i vijek $u$ kojemu se vlada nad pisanom riječju. Pojavom Guttembergova tiskarskog stroja utjecaj Crkve počet će slabjeti, a težnja za većim slobodama uzima sve više maha. Crkva je anatemisala Gutembergov pronalazak nazvavši ga „đavoljim izumom“. 
U kasnom srednjem vijeku objavljeno je nekoliko udžbenika ili priručnika o svećeničkim dužnostima. Ako se oni usporede s onima s konca XVI stoljeća, vidjet će se da se njihov sadržaj izmijenio.

Srednjovjekovni priručnici bili su više liturgijski, mješavina pastirskih obaveza i ponašanja u crkvi. Oni stavljaju jači naglasak na točnom izvršavanju obrednih gesta. Služba se svodi na obrednu kontrolu (kod katolika), važna je formulacija, a ne sadržaj, tj. odnos pojedinca prema sadržaju. Reformacija naglasak stavlja na interpersonalnu interakciju Boga i čovjeka.

Pravi obred bit će svečan i sadržajan, zahvaljujući unutarnjem poštovanju, ako je uspostavljena duhovna veza između čovjeka i Boga. Komuniciranje koje se svelo na "znanstvenu i pravnu formu" dovelo je do duhovne otuđenosti, do komuniciranja između subjekta i objekta. Priručnici o svećeničkim dužnostima bili su namijenjeni i propovjednicima za koje je propovjedaonica $\mathrm{u}$ isto vrijeme $\mathrm{i}$ radost i prijestol, propovjednicima koji unose stvaralački element u svoje propovijedi. Naglasak se stavlja na važnost učenja i obrazovanja. Izučavaju se humanističke znanosti usporedo sa stjecanjem teološkog znanja.

Valja reći nekoliko riječi i o novom obrascu ophođenja između vjerništva i svećenstva koga unosi reformacija. Ako usporedimo protestantskog propovjednika u "Svećeniku hrama" od Georga Herberta s katoličkim svećenikom u "Uputstvima za svećenike" od Karla Bromejskog /8/, ustanovit ćemo da je Herbertov propovjednik zamišljen kao druželjubiv, manje izdvojen od puka; on živi među njima i kao prijatelj i kao predvodnik duša, prima ih za svoj stol. Kod Bromejskog svećenik treba odbiti svaki poziv vjernika na večeru ili ručak. „On je manje druželjubiv i na distanci je od vjerništva. Dva modela ostat će dulje vremena $u$ koliziji“./9/

Novi značaj propovijedanja koji je uvela reformacija zahtijevao je i drugačiji način gradnje crkava i opremanje njihove unutarnjosti.

Istina, protestanti su za vrijeme reformacije izgradili malo crkava, dijelom i stoga što je dosta štete nanijelo rušenje samostana, a dijelom i stoga što su neke crkve propadale zbog nedostatka sredstava, jer su sljedbenici, seljaci i puk, bili siromašni.
Jedna od prvih reformatskih crkava, crkva Svetog Pavla na Covent Gardenu, sagrađena je 1631. godine.

Među reformiranim kršćanima najveća nova građevina bila je veliki hugenotski hram u Šaretonu (1623) u obliku pravilnog četverokuta $\mathrm{s}$ dva reda galerija, propovjedaonicom i malim brojem drugih detalja. Propovjedaonica je dobila dominantan položaj. Ona je potiskivala oltar, nalazeći se ispred, ili čak iznad njega. Osim propovjedaonice, uvedeno je tzv. postolje za čitanje kao neophodan dio crkvenog namještaja, obično okrenut vjernicima, dok su leđa onoga koji čita bila okrenuta istoku.

Već smo istaknuli tendenciju protestantskog propovjednika u približavanju puku svojim ponašanjem i odnosom prema njemu. Taj proces približavanja zapaža se i u odijevanju. Istina, na samom početku reformacije te razlike nisu bile tako očite, ali su neki detalji naglašavali određeni proces reforme i u ovome aspektu. Kalvin se na nekim crtežima predstavlja u prsniku $s$ hlačama, a većina propovjednika nije htjela nositi nikakvu odjeću po kojoj bi se razlikovali od vjernika. Srednjovjekovno odijevanje svećenika gubi svoj značaj u razvoju reformacije, ali sama uloga propovjednika bitno je izmijenjena. Propovjednik predstavlja prenosioca božanskih objava $u$ uspostavljanju komunikativnih odnosa čovjeka i Boga.

Osnovno pravilo za odijevanje propovjednika mora biti usklađeno prema vjerništvu koje na njega reagira na određeni način. Važni faktori su okolnosti, kulturna sredina, kao i sam propovjednik. Često modne promjene u duljini frizure, brade, brkova, onemogućavaju neka utvrđena pravila. Propovjednik koji je svjestan mentaliteta svoje publike i njezinih standarda neće dopustiti da mu vanjština bude zapreka za uspješno obnašanje misije.

Promjene $\mathrm{u}$ izgledu, kao duljina kose, povremeno puštanje brade, izazivaju kod vjernika negativne reakcije $i$, s druge strane, govore $o$ nezrelosti ličnosti, a to ruši ugled i slabi povjerenje u propovjedničku službu. Odjeća i pojava propovjednika pomažu nam da stvorimo sud o njemu, a da zaista i ne znamo zašto smo to učinili. Odijelo ne samo da "čini čovjeka", nego "odijelo govori o čovjeku" /10/. Na taj je način 
autoritet vanjskog izgleda zamijenjen autoritetom, tj. kvalitetom poruke.

\section{Zaključak}

Pojavom reformacije $\mathrm{u}$ XVI stoljeću scena na društvenom, ekonomskom, političkom, kulturnom i vjerskom životu se mijenja. Pojavljuju se crkveni dokumenti koji stvaraju uvjete za rađanje nove društvene svijesti. Ona uvjetuje i novi komunikativni obrazac $u$ procesu shvaćanja i razumjevanja demokracije. Odlike te i takve demokracije ogledaju se u kulturnom razvoju, duhovnom stvaralaštvu, u shvaćanju osobnih vrijednosti, osvajanju osobne slobode kao božanske

datosti satkane u strukturi ljudske ličnosti - jer sloboda je čovjekovo prirodno pravo.

Reformacija $\mathrm{u}$ XVI stoljeću pred-stavlja duhovni preobražaj i početak nove epohe $u$ definiranju ličnosti, čovjekovih prava i odgovornosti. Riječ je o prelasku na narodni suverenitet i stvaranje države putem fiktivnih ugovora ili ustava.

Bog ne rabi silu, već djeluje na čovekove komunikacijske sposobnosti koje ga dovode do voljnog prihvaćanja ponuđene ideje. U neprekidnom varijabilnom nastojanju da ukaže na stvaralački proces vjere kao fundamentalnog obilježja religioznosti, protestantizam mora primjenjivati metode neizravnog uvjeravanja. Ovaj model koristi praksu uvjeravanja, (za razliku od persuazivne komunikacije koja nagovora i ubeđuje) sjedinjujući tako emocije s razumom i voljom.

Izučavajući strategiju ovog modela komuniciranja, koga donosi protestantizam, kao stvaralačkog čina, u domenu interpersonalnih komunikacija, doći ćemo do zaključka koji ukazuje da on svojom praksom nudi koncepte i obrasce ophođenja u raznim socijalnim skupinama.

Ljudi traže informacije koje će im pomoći da shvate razloge radi kojih djeluju onako kako djeluju i kako žele da djeluju.

Kada je riječ o usvajanju ideja, onda se rabi sloboda jer ljudi žele od svojih prijatelja ili od onih u koje imaju povjerenje dobiti savjet ili uvjeravanje o vrijednosti ideje koja im se nudi, a ne nameće se silom. Reformacija je donjela buđenje nove društvene svijesti koja se očituje na svim razinama ljudskog djelanja i življenja. Današnje poimanje slobode proizilazi iz filozofskih i političkih doktrina koje su dominirale u zapadnom svijetu poslije XVI stoljeća. Reformacija i razvoj misli stvorili su uz renesansu naš ideal slobode, koji je nerazdvojno vezan uz naš pojam civilizacije. Sloboda je postala životna potreba svih naroda svijeta. Sloboda nije sama po sebi cilj, nego je sredstvo kojim se do cilja dolazi u zaštiti života.

Poštovanje čovjeka rezultat je poštovanja Boga. Ideja slobode, kako građanske tako i vjerske, konačno se svodi na teološku bazu. Protestantsko razumjevanje slobode temelji se na biblijskom poimanju čovjeka, imago Dei. Iz tog razloga, sloboda je u prvom redu, u svojoj suštini, unutarnje stanje, i nikakav vanjski utjecaj ne može $u$ tom pogledu djelovati na pojedinu osobu. Tako, slobodno možemo reći da unutarnja sloboda ne ovisi od vanjskih uvjeta.

Vrijednost slobode nalazi se $\mathrm{u}$ nepovredivoj svetosti ljudske savjesti, jer čovjek poseduje određena i neotuđiva prava, a temelj svih ljudskih moralnih prva je sloboda.

Notes

/1/Berđajev, N. (1992). Carstvo duha i carstvo ćesara, Dobra vest, Novi Sad, str. 76.

/2/ Humbolt, von V. (1991). Ideje za pokušaj određivanja granica delotvornosti države, Dobra vest, Novi Sad, str. 76.

/3/ Luter, M., Komentar o Veličanstvu iz 1521. god.

/4/ Luter, M., O privremenom autoritetu iz 1523. god.

/5/Testas, G. (1982). Inkvizicija, Kršćanska sadašnjost, Zagreb, str. 2.

/6/ Ibidem, str. 23.

/7/ Luter, M., Komentar o Veličanstvu iz 1525. god.

/8/ Čedvik, O. (1986). Istorija reformacije, Dobra vest, Novi Sad, str. 303.

/9/ Ibidem, str. 73.

/10/Ibidem, str. 300 . 


\title{
UNDERSTANDING OF FREEDOM AS A NATURAL RIGHT
}

\author{
Zdravko Šorđan \\ Institute of Theology, Belgrade, Serbia
}

\begin{abstract}
Creating of social movement is usually developed as a reaction to the actual state in socety, so they are created as a consequence of spritual unpleasure and revolt because of deviant phenomena, as a willing for new indentity, internal unrest, spritual progres-toward movement, as a trying to reach higher goals; as a labor in order to get a theory be translated into practicing work. In sases when they are genuinely, motivated, they are created as "holly ecstatics".

But without these kind of ecstatics there is no spiritual phenomenon and there cannot be such a phenomenon. "Each person who dismiss an utopia puts a mankind in a trap of material rationalizing, also leaves a mankind on "Willing-forpower" manipulation".(A. Heller). These social movements, in other words, are developed as a consequence of unsatisfied needs, as a reaction to the spritual anemia and passive human behavior, so they want to reach higher and greater spiritual changes. Each kind of newborn life has its own rhythm of living which knows nothing about traditional social phenomena and which, in the same time, tries to reach harmony way of co-living.
\end{abstract}

Key words

freedom, reformation movement, the movement, freedom, society, sprituality, change 